\section{A) Check for updates}

Cite this: Food Funct., 2020, 11, 1891

\title{
Correction: Benefits of the ipowder® extraction process applied to Melissa officinalis L.: improvement of antioxidant activity and in vitro gastro-intestinal release profile of rosmarinic acid
}

\author{
Valérie Bardot, ${ }^{a}$ Anaïs Escalon, ${ }^{a}$ Isabelle Ripoche, ${ }^{\mathrm{b}}$ Sylvain Denis, ${ }^{\mathrm{c}}$ Monique Alric, ${ }^{\mathrm{c}}$ \\ Sandrine Chalancon, ${ }^{\mathrm{c}}$ Pierre Chalard, ${ }^{\mathrm{b}}$ César Cotte, ${ }^{\mathrm{a}}$ Lucile Berthomier, ${ }^{\mathrm{b}}$ \\ Martin Leremboure ${ }^{b}$ and Michel Dubourdeaux ${ }^{\star a}$ \\ Correction for 'Benefits of the ipowder ${ }^{\circledR}$ extraction process applied to Melissa officinalis L.: improvement of \\ antioxidant activity and in vitro gastro-intestinal release profile of rosmarinic acid' by Valérie Bardot et al., \\ Food Funct., 2020, DOI: 10.1039/c9fo01144g.
}

DOI: $10.1039 / \mathrm{dOfo} 90001 j$

rsc.li/food-function

The authors regret that there were errors in the first paragraph of section 2.1. The text originally read, "The leaves of M. officinalis were collected in Aubiat (France) in June 2015 and identified by Gilles Thébault from the herbarium of the Museum d'Histoire Naturelle Henri-Lecoq (Clermont-Ferrand, France) in which a voucher specimen was deposited (CLF106452). This herbarium is registered with the International Association for Plant Taxonomy, the head office of which is located in the New York botanical garden". The text should read, "The leaves of M. officinalis were collected in Aubiat (France) in June 2015 and identified by Gilles Thébaud from the UniVegE service of the University of Clermont-Ferrand (France) in which a voucher specimen was deposited (CLF106452). CLF is registered in the Index Herbariorum of the New York botanical garden".

The Royal Society of Chemistry apologises for these errors and any consequent inconvenience to authors and readers.

\footnotetext{
${ }^{a}$ PiLeJe Industrie, Naturopôle Nutrition Santé, Les Tiolans, F-03800 Saint-Bonnet-de-Rochefort, France.E-mail: m.dubourdeaux@pileje.com ${ }^{b}$ Université Clermont Auvergne, CNRS, SIGMA Clermont, Institut de Chimie de Clermont Ferrand, BP 10448, F-63000 Clermont Ferrand, France ${ }^{c}$ Université Clermont Auvergne, INRA, UMR454 MEDIS, F-63000 Clermont Ferrand, France
} 